\title{
Econometric Models of Attracting Investment into Production in Uzbek Industry
}

\author{
Aktam Burkhanov \\ Dr. of economic sciences, Chair of department of Management of Tashkent State Technical University,
}

\begin{abstract}
In this article, is analysed relationship between GDP and investments and proven on the basis of econometric models. Model of GDP determination is built on the basis of Solow model with the help of CobbDouglas production function. Econometric models for calculating the effectiveness of attracting more investment to production in Uzbek economy are analyzed using dynamic econometric models constructed using Solow model.
\end{abstract}

Keywords: Investment costs, investment limits, capital resources, the main production funds, human resources, economic dynamics model.

\section{Introduction}

It is well known that the GDP and investments are closely related, and wide attractionof investment can lead to growth in GDP.Relationship between the investment and economic growth are viewed as the main factors of a number of studies. Investment not only affects the growth of GDP, but also plays an important role in the structural changes in the production of GDP. Therefore, the relationship between the GDP and investment and creating models of investment growth are significant. Thus, it is desirable to create a dynamic economic model.

Having analysed dynamic economic models, the theory of economics can highlight the use of two lines:

1) Models not linked to the real economy, with less specific examples for modeling and experimental uses;

2) Modeling possible directions of economic development of multiple studies of real economic dynamics and coordinated in order to make management decisions.

It should be noted that the various models of the first type are built more than the second type. Because in their attempts to create models of real economic dynamics that are difficult to unravel the academic economists faced a lot of difficulties, as a result of which they were forced to build abstract models. As a result, the practical application of the model bring about unprecedented results.

Using these models taking into account the characteristics of Uzbek economy, in our view, allows to increase the role of investment in sustainable growth of GDP.

\section{Literature review}

Economist scientists have created models with various aspects of the connection between GDP and investment levels. Scientific and practical significance of this models is that the connection between investment and GDP different aspects have been proven in practice. For example, the relationship between increase in the volume of investment and growth rate of GDP (J.M. Keynes model), the relationship between increase in investment and growth of macreconomic indicators (Cobb-Douglas function) are proven to have practical significance.

R. Solow who created the first model of economic dynamics, saw it as the complex function of Gross National Product (GNP) and capital resources.Studying GDP by dividing it into two components, namely consumption and investments was carried out for the first time by academic economist J.M.Keynes [Keynes, 1993]. During the scientific experiment, Keynes suggested to study the GDP by dividing it into two parts: consumption and savings. Also, he concluded that «as the savings are redirected into production as investment, this will lead to growth of real income». In 1928, C. Cobb and P. Douglas created economic growth model where GDP is the function of the relationship between physical capital and human resources [Robert J. Barro, Xavier Sala-I-Martin, 2003]. The model of production function looks as follows:

$$
Y_{i}=\beta_{1} X_{2 i}^{\beta_{2}} X_{3 i}^{\beta_{3}} e^{u_{i}}
$$

Here:

$\mathrm{Y}$ - production, GDP;

$X_{2}$ - human resources employed to create the GDP;

$X_{3}$ - capital resources exploited to create the GDP;

$u$ - stochastic parameter, function error; 


$$
\boldsymbol{e} \text { - natural logarithmic base. }
$$

Specific features of Cobb-Douglas model include:

$-\beta_{2}$ is the elasticity of production relative to workforce, and when the capital was taken as a constant factor, shows the percent change in the production the as a result of $1 \%$ increase in labor force;

$-\beta_{3}$ shows the percentage change in production as a result of $1 \%$ increase in capital resources while labor force is constant

$-\beta_{2}+\beta_{3}$-the sum of the two shows the change in production as a result of proportional change in production factors. If this sum is equal to 1 , then 2 -fold increase in the factors of production leads to a 2 -fold increase in the production, and 3 -fold increase in factors of production also increase production 3 times and etc. If the otal of this sum is smaller than 1, then the result is diminishing. For example, a 2 -fold reduction in production factors leads to a 2 -fold reduction in manufacturing of the product.

All variables used in the Cobb-Douglas model are considered stochastic with $10 \%$ probability according to Dickey-Fuller testAs is known, in accordance with the method of OLS, for variable coefficients to be a real, model errors should have normal distribution as well as exogenous variables and model error should have no correlation and should fulfill other conditions.

O. Blanchard, a professor at the University of Massachusetts in the United States has proven the connection between investment and GDP using a model [Blanchard, 2003]. This is a very simple model (I=Ï) where investments are not significantly sensitive to changes in production.

In O. Blanchard's model increase in investment with the purpose of increasing production which results in increase in GDP is not reflected.

According to G. Mankiw's conclusion [Mankiw, 2007], if we take into account that national savings equal to Y-C-G, GDP and investment will look as follows:

Here:

$$
\begin{gathered}
\mathrm{Y}-\mathrm{C}-\mathrm{G}=\mathrm{I}+\mathrm{NX} \\
\mathrm{S}=\mathrm{I}+\mathrm{NX}
\end{gathered}
$$

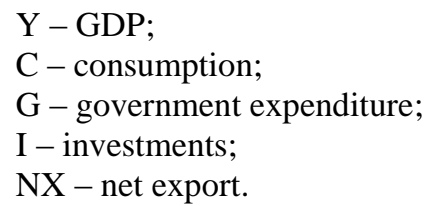

G. Mankiw considers net exports to be equal to net capital expenditures and offers the following equation [Mankiw, 2007]:

$\mathrm{S}=\mathrm{I}+\mathrm{NCO}$

He ultimately concludes that the national savings should be equal to the sum of the domestic investment and net capital expenditure. S.V. Chepel achieved the following important scientific results in the process of applying the theoretical model of attracting direct foreign investments into the national economy in practice [Chepel, 2014]: - GDP deflator's decline of 10 percentage points in analyzed countries, the volume of direct foreign investments in GDP increased 0.8 percentage points the decrease in the rate of inflation increase in direct foreign investments in the share of GDP (2007 GDP deflator cut inflation at the level of 2000 increased by 23 percentage points in this period, the share of direct foreign investments in GDP to increase by 0.8 per cent to 3.2 per cent) The development of the banking system, involved in the improvement of the quality indicators of the national economy will increase the volume of direct foreign investments

Increasing average index of economic freedom to the level of developing countries (57.5\%) in Russia, Ukraine, Kazakhstan and Uzbekistan to increases foreign direct investment by 3,6-3,7\% compared GDP.

We believe that in foreign direct investment attracting model, regulatory changes regarding the investment should be considered. The reason for this is that the decline in investment does not allow us to maintain the stability.

\section{Building the empirical model}

If current GDP is taken as $\mathrm{Y}_{\mathrm{t}}$, consumption $-\mathrm{C}_{\mathrm{t}}$, investments $-\mathrm{I}_{\mathrm{t}}$, then according to the conclusion of Keynes the following formula will be true:

$Y_{t}=C_{t}+I_{t}$

Volume of consumer demand consists of two indicators - consumption determined by minimum hygiene standards and income growth as a result of additional parts Keynes suggested that the second part is reflected as a percentage of GDP in the previous period: $c Y_{t-1}$

In this case, this year's consumer demand constitutes linear function of last year's GDP: 


$$
C_{t}=C+c Y_{t-1}
$$

If we input this into (1) formula, we get:

$$
\mathrm{Y}_{\mathrm{t}}=\mathrm{C}+\mathrm{c} \mathrm{Y}_{\mathrm{t}-1}+\mathrm{I}_{\mathrm{t}}
$$

Here:

$\mathrm{c}$ - share of consumption in GDP.

If investments are taken as constant, then we will have first ortder autoregressive equation. Propensity to consume affects GDP growth rate ( $\mathrm{c}$ - share). As it is autoregressive model, we can illustrate different trajectories of GDP growth by setting initial condition and changing the value of propensity to consume. We can create a closed model by combining Keynesian model and Cobb-Douglas production and by defining different parameters we can estimate different growth projections of the economy. In Solow model, GDP is determined with the help of Cobb-Douglas production function as follows:

$$
Y_{t}=a K_{t}^{\alpha} L_{t}^{1-\alpha}
$$

In a given time $(\mathrm{t}) \mathrm{GDP}\left(\mathrm{Y}_{\mathrm{t}}\right)$ consists of investments $\left(\mathrm{I}_{\mathrm{t}}\right)$ and consumption $\left(\mathrm{C}_{\mathrm{t}}\right)$ :

$$
Y_{t}=I_{t}+C_{t}
$$

Here the focus is on investment rather than consumption and share of GDP which is expected to be allocated for investments can be given as propensity to save $-\rho$ :

$$
I_{t}=\rho Y_{t}
$$

As is known, attraction of investments will lead to the growth of production funds for the next year $K_{t+l}$, which is determined through old funds $K_{t}$ by taking into account the share of funds from last year's production $\mu$ :

$$
K_{t+1}=(1-\mu) K_{t}+I_{t}
$$

If the number of terms in economy are labelled as $L_{t+1}$, taking into account annual growth rate of terms $(v)$,it can be calculated through current number of terms:

$$
L_{t+1}=(1+v) L_{t}
$$

GDP, Investments and other parameters can be calculated taking into account next year's production funds and number of terms. Equations (7) - (11) are mathematic expressions of Solow model. This model can be implemented in economic development of sectors and as well as used in working out suggestions and conclusions in further development of a particular sector.

\section{Results of the research}

In order to construct the model of economic dynamics, the indices in the table will be transferred to unlimited figures.

Simple order production function, coeffcients of which were calculated using method of least squares, looks like this:

$$
\mathrm{Q}_{\mathrm{t}}=1,01 \mathrm{~K}_{\mathrm{t}}^{1,33} \mathrm{~L}_{\mathrm{t}}^{0,65}
$$

Table: Principal indicators of manufacturing in Uzbekistan

\begin{tabular}{|l|l|l|l|l|l|l|l|l|l|l|l|l|}
\hline & & & & & & & & & & & & \\
\hline $\begin{array}{l}\text { Share of investments in } \\
\text { main capital, \% (this } \\
\text { shows invesmtents into } \\
\text { main indisutrial capital } \\
\text { as a percentage of } \\
\text { investments made }\end{array}$ & 32,6 & 34,3 & 37,7 & 34,5 & 28,4 & 30,4 & 33,8 & 34,2 & 34,2 & 37,4 & 37,8 \\
\hline $\begin{array}{l}\text { Share of main funds in } \\
\text { manufacturing (\%) (this } \\
\text { shows main funds of } \\
\text { industrial production as } \\
\text { a percentage of main } \\
\text { funds throughout the }\end{array}$ & 35,5 & 39,1 & 34,7 & 28,9 & 28,7 & 29,6 & 30,3 & 31,3 & 32,9 & 32,8 & 33,2 \\
\hline $\begin{array}{l}\text { Growth rates of industry } \\
\text { compared to last year, in }\end{array}$ & 107,2 & 110,8 & 112,1 & 112,7 & 109,1 & 108,5 & 106,4 & 107,9 & 109,6 & 108,3 & 108,0 \\
\hline
\end{tabular}




\begin{tabular}{|c|c|c|c|c|c|c|c|c|c|c|c|}
\hline $\begin{array}{l}\text { Number of people } \\
\text { working } \\
\text { sectors (in thousands) } \\
\text { (this represents average } \\
\text { number of workers }\end{array}$ & 616,7 & 614,7 & 618,3 & 600,4 & 579,0 & 611,6 & 644,2 & 670,5 & 680,3 & 682,4 & 685,7 \\
\hline
\end{tabular}

Source: Annual statistics compilation. - Tashkent: State Statistics Committe of the Republic of Uzbekistan, 2013-2015. Industry of Uzbekistan. - Tashkent: State Statistics Committe of the Republic of Uzbekistan, compiled by the author based on the information from collection of statistical data 20062015.

Thus, in Uzbekistan in the years 2005-2015 capital resources elasticity is 1.33 units, labor resources elasticity is 0.65 units. Production function itself is not enough to construct the model of economics dynamics. It is important to describe other aspects of this model too. Because GDP is divided into consumption and savings, calculating the share of GDP allocated for investments $\rho$ is necessary. This share turned out to be 0.12 , which means that the level of investments in year $t$ is determined woth the help of propensity to save as follows:

$$
\mathrm{I}_{\mathrm{t}}=0,12 \mathrm{Q}_{\mathrm{t}}
$$

Investments lead to rise in the main funds of the following year $K_{t+1}$ and calculated through the main funds of the last year $\mathrm{K}_{\mathrm{t}}$ taking into account discounted funds of the previous year $\mu$. While calculating the share of discounted funds coeffcient of main funds was negative at -0.65 . That maens funds are not being discounted but are rising and this rise significantly more than the volume of investments. In turn, this means that production funds are working with very little power. Taking this into account dynamics of capital resources in during the period under study can be given as follows:

$$
\mathrm{K}_{\mathrm{t}+1}=1,065 \mathrm{~K}_{\mathrm{t}}+\mathrm{I}_{\mathrm{t}}
$$

Annual rise in economic bands constituted 1.01, therefore number of bands in economy is calculated through current number of bands $\mathrm{L}_{\mathrm{t}}$ taking into account annual growth rate of bands $(v)$ :

$$
\mathrm{L}_{\mathrm{t}+1}=1,01 \mathrm{~L}_{\mathrm{t}}
$$

It is clear from the models (10) - (13), to develop the manufacturing industry it will be required to implement a number of measures, namely, increasing the number of bands in the economy through attracting more investments, also because manufacturing funds are running very low energy production, using their potential more efficiently will lead to further development of industrial manufactruing.

\section{Conclusion}

1. As directing investment into different sectors of the economy is important, model of attracting foreign direct investments should be constructed and changes in the level of investments should be taken into consideration in this model. Because, decrease in investment levels will not allow to maintain sustainable volume of foreign direct investments investments.

2. The further attraction of investments into the Uzbek industry in the coming years will lead to an increase in the volume of production.

3. The volume of main funds in the country is increasing instead of being discounted and at the moment this growth is higher than the level of attracted foreign direct investments. This means that manufacturing funds are running with very low intensity.

4. The increase in the volume of investments in the industry in the country is necessary to increase the number of terms.

\section{References}

[1]. Keynes. J.M. (1993): Selected works. - M.: Economics. - pp. 224-518.

[2]. Robert J. Barro, Xavier Sala-I-Martin (2003): Economic growth, New York: McGraw-Hill, Inc. -pp. 158-159.

[3]. Blanchard Olivier (2003): Macroeconomics. Third Edition. Pearson Education Inc.; Prentice Hall. -p. 52.

[4]. Mankiw, N. Gregory (2007): Principles of Macroeconomics. 4th edition, Thomson South-Western. -pp. 346-347.

[5]. Chepel, S.V., (2014): Systematic analysis and modeling of perspectives of sustainable development of national economy of Uzbekistan. Monograph. -Tashkent: IFMR. -pp. 120-122.

[6]. Annual statistics compilation. - Tashkent: State Statistics Committe of the Republic of Uzbekistan, 2013-2015.

[7]. Industry of Uzbekistan. - Tashkent: State Statistics Committe of the Republic of Uzbekistan, 2006-2015. 